\title{
Prognostic significance of anterior mitral valve leaflet length in individuals with a hypertrophic cardiomyopathy gene mutation without hypertrophic changes
}

\author{
Hannah G. van Velzen ${ }^{1}$ (D) Arend F. L. Schinkel ${ }^{1} \cdot$ Myrthe E. Menting $^{1} \cdot$ Annemien E. van den Bosch $^{1}$. \\ Michelle Michels ${ }^{1}$
}

Received: 24 January 2018 / Accepted: 1 May 2018 / Published online: 6 June 2018

(c) The Author(s) 2018

\begin{abstract}
Purpose Previous studies suggest that anterior mitral valve leaflet (AMVL) elongation is a primary phenotypic feature in hypertrophic cardiomyopathy (HCM). Our aim was to assess AMVL length in individuals with HCM gene mutations and in healthy controls and to identify predictors of the development of HCM during follow-up.

Methods A total of $133 \mathrm{HCM}$ mutation carriers and 135 controls underwent cardiac examination including electro- and echocardiography. AMVL length was measured in the parasternal long axis and apical three chamber view during diastole. Univariate and multivariable cox proportional hazard regression analyses were performed to identify predictors of HCM.

Results There were no significant differences between HCM mutation carriers and controls regarding age and sex. In the parasternal long axis view, AMVL length was similar in mutation carriers and controls ( $24 \pm 4$ vs $24 \pm 4 \mathrm{~mm}, p=0.8)$. In the apical three chamber view, AMVL were shorter in mutation carriers $(29 \pm 4$ vs $30 \pm 4 \mathrm{~mm}, p=0.02)$. When averaged for both views, AMVL length was similar in mutation carriers and controls $(27 \pm 3$ vs $27 \pm 3 \mathrm{~mm}, p=0.2)$. During $5.8 \pm 3.0$ years follow-up, 13 (14\%) HCM mutation carriers developed HCM. Pathological Q wave (hazard ratio 9.89, $p=0.004$ ), E/e' ratio (hazard ratio 2.52, $p=0.001$ ), and maximal wall thickness (hazard ratio 2.15, $p=0.001$ ) were independent predictors of HCM. AMVL length was not predictive of the development of HCM.

Conclusions AMVL length is similar in HCM mutation carriers and controls. AMVL length is not predictive of the development of HCM, in contrast to pathological Q wave, E/e' ratio, and maximal wall thickness.
\end{abstract}

Keywords Echocardiography $\cdot$ Genetics $\cdot$ Hypertrophic cardiomyopathy $\cdot$ Mitral valve $\cdot$ Screening

\section{SOMMARIO}

Obiettivi Studi precedenti suggeriscono che l'allungamento della cuspide anteriore della valvola mitrale (LAVM) è una caratteristica fenotipica primaria nella cardiomiopatia ipertrofica (HCM). Il nostro obiettivo era quello di valutare la lunghezza del LAVM in individui con mutazioni del gene HCM e nei controlli sani e di identificare i predittori dello sviluppo di HCM durante il follow-up.

Metodi Un totale di 133 portatori di mutazione HCM e 135 controlli sono stati sottoposti ad un esame cardiologico che comprendeva un elettrocardiogramma ed ecocardiografia. La lunghezza del LAVM è stata misurata durante la fase diastolica in proiezione parasternale asse longitudinale ed in proiezione 3 camere apicali. Le analisi di regressione del rischio proporzionale coassiale univariata e multivariata sono state eseguite per identificare I predittori di HCM.

Risultati Non sono risultate differenze significative tra portatori di mutazione HCM e controlli per quanto riguarda età e sesso. Nella proiezione parasternale asse lungo, la lunghezza del LAVM era simile nei portatori di mutazione e controlli ( $24 \pm 4$ vs $24 \pm 4 \mathrm{~mm}, p=0.8$ ). Nella proiezione 3 camere apicale, i valori del LAVM erano minori nei portatori di mutazione $(29 \pm 4$ vs $30 \pm 4 \mathrm{~mm}, p=0.02)$. Eseguendo la media dei valori per entrambe le proiezioni, la lunghezza del LAVM era simile nei portatori di mutazione e nei controlli $(27 \pm 3$ vs $27 \pm 3 \mathrm{~mm}, p=0.2)$. Durante un periodo di follow-up di $5.8 \pm 3.0$ anni, 13 (14\%) dei portatori della mutazione HCM hanno sviluppato HCM. L'onda Q patologica (hazard ratio 9.89, $p=0,004$ ), il

Extended author information available on the last page of the article 
rapporto $\mathrm{E} / \mathrm{e}^{\prime}$ (hazard ratio 2.52, $p=0.001$ ) e lo spessore massimale della parete (hazard ratio $2.15, p=0.001$ ) sono risultati predittori indipendenti di HCM. La lunghezza del LAVM non era predittiva di sviluppo di HCM.

Conclusioni La lunghezza del LAVM è simile nei portatori della mutazione HCM e nei controlli. La lunghezza del LAVM non è risultata predittiva dello sviluppo di HCM, a differenza dell'onda Q patologica, del rapporto E/e', e dello spessore massimale della parete.

\section{Introduction}

Hypertrophic cardiomyopathy (HCM) is a genetic cardiac disease with an estimated prevalence of 1:500-1:200 [1-3]. The diagnosis is based on the presence of a maximal wall thickness $\geq 15 \mathrm{~mm}$ in index patients and $\geq 13 \mathrm{~mm}$ in relatives, that is not solely explained by abnormal loading conditions [2]. A pathogenic HCM mutation is identified in $40-60 \%$ of patients with HCM [2, 4]. Presymptomatic genetic testing of relatives has led to the identification of HCM gene mutation carriers who do not fulfill the echocardiographic criterion of HCM [5]. HCM mutation carriers are at risk of developing HCM [5]. Conflicting data exists on whether the anterior mitral valve leaflets (AMVL) are elongated in mutation carriers and whether AMVL elongation is a predictor of the development of HCM during follow-up [6-11]. The aim of this study was to assess AMVL length in HCM mutation carriers and healthy controls and to determine the prognostic significance of AMVL length in HCM mutation carriers for the development of HCM during follow-up.

\section{Methods}

\section{Study design and population}

This single-center retrospective case-control and cohort study included 133 HCM mutation carriers without clinical expression of HCM who were clinically evaluated at our cardio-genetic outpatient clinic between the years 2004-2017. Genetic assessment and the family screening strategy at our center have been described previously $[12,13]$. For comparison, 135 healthy controls underwent cardiac evaluation [14]. Controls were recruited via an advertisement. Inclusion criteria were normal physical examination, normal electrocardiography (ECG), and left ventricular (LV) ejection fraction $>51 \%$; exclusion criteria were prior cardiovascular disease or risk factors consisting of hypertension, diabetes mellitus, and hypercholesterolemia, systemic disease, medication known to influence cardiac function including thyroid medication (with the exception of asthma inhalers), professional athletes, body mass index $>40$ and women with breast implants [14]. The study conforms to the principles of the Declaration of Helsinki. All patients gave informed consent for inclusion in the registry and local institutional review board approval was obtained.

\section{Clinical evaluation}

Clinical evaluation included medical history, physical examination, ECG, and transthoracic echocardiography. Standard 12-lead ECG was performed in the supine position during quiet respiration. LV hypertrophy was evaluated with the Romhilt-Estes criteria. Pathological Q waves were defined as duration $>40 \mathrm{~ms}$ or depth $>30 \% \mathrm{R}$ wave in $\geq 2$ leads. $\mathrm{T}$ wave inversion was defined as $\geq 3 \mathrm{~mm}$ in $\geq 2$ leads. Echocardiographic studies were analyzed according to the guidelines $[15,16]$. Maximal wall thickness, left atrial size, leaflet and chordal systolic anterior motion of the mitral valve, and resting LV outflow tract peak velocity were assessed. LV outflow tract gradient was calculated with the Bernoulli equation. LV systolic function was categorized as: good (LV ejection fraction $>51 \%$ ), mildly reduced (LV ejection fraction 41-51\%), moderately reduced (LV ejection fraction $30-40 \%$ ), and poor (LV ejection fraction <30\%) [16]. LV diastolic function was defined as normal, abnormal relaxation, pseudonormal or restrictive filling, based on Doppler mitral inflow pattern parameters including early (E) and late (A) LV filling velocities, E/A ratio, and tissue Doppler imaging-derived septal early diastolic velocities $\left(\mathrm{e}^{\prime}\right)$ [17]. HCM during follow-up was defined as a maximal wall thickness $\geq 13 \mathrm{~mm}$ according to the guidelines [2].

\section{AMVL measurements}

AMVL length was measured in the parasternal long axis (PLAX) view and in the apical three chamber (A3C) view, during diastole and with the leaflet maximally extended. In the PLAX view, leaflet length was defined as the distance from the tip of the leaflet to the junction between the anterior leaflet and the posterior aortic wall (hinge point), according to Klues et al. [18]. In the A3C view, leaflet length was defined as the distance from the tip of the leaflet to the insertion of the noncoronary aortic leaflet, according to Alhaj et al. [19]. Examples of AMVL measurements in both views are shown in Fig. 1. All AMVL measurements were 

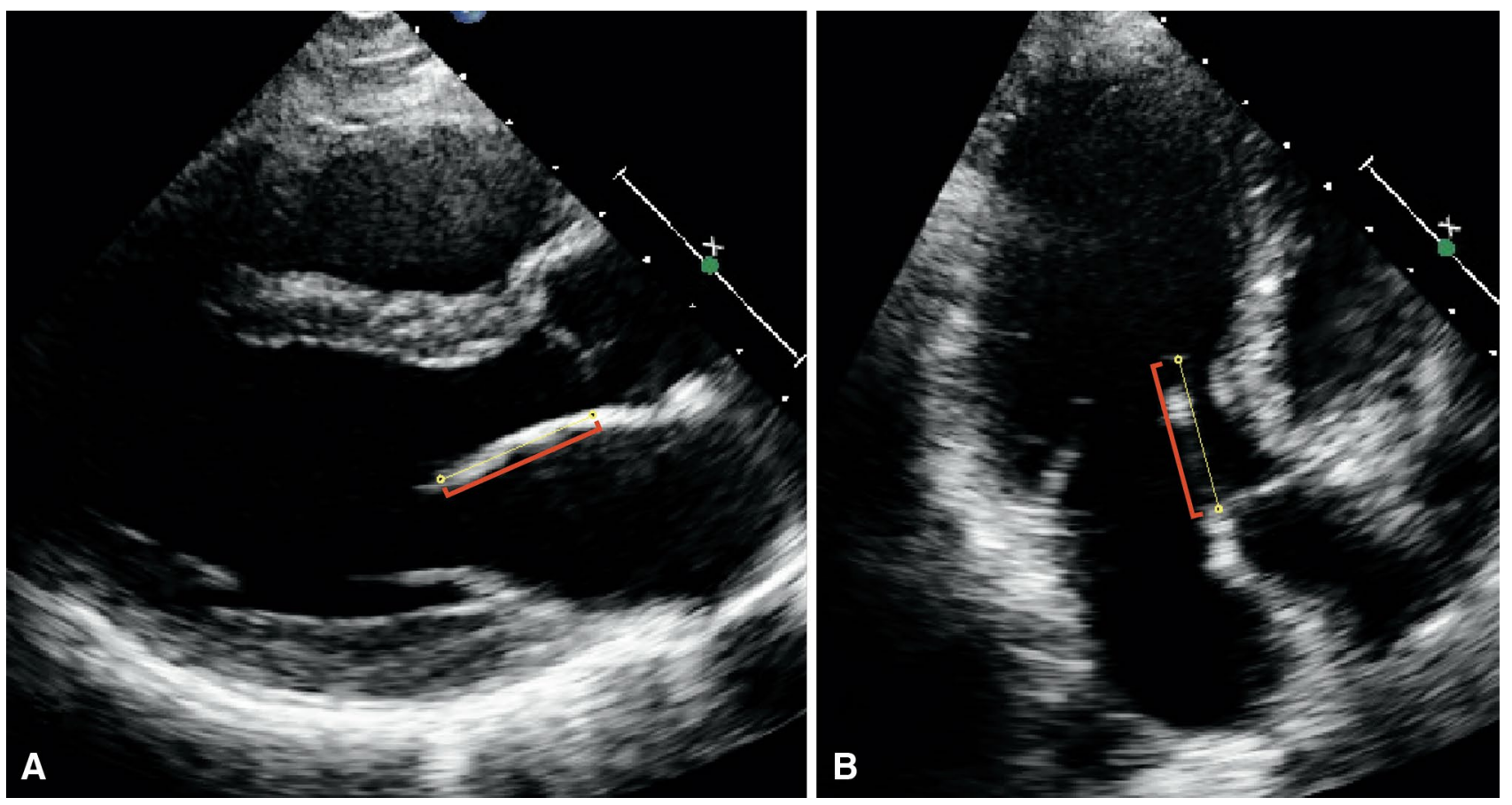

Fig. 1 Example of anterior mitral valve leaflet length (AMVL) measurements in a hypertrophic cardiomyopathy gene mutation carrier without hypertrophic changes. In the parasternal long-axis view, a the

performed by one reader. For intraobserver variability, one reader independently measured 40 AMVLs in the PLAX view and 40 AMVLs in the A3C view in an identical fashion on two occasions. For interobserver variability, two readers independently measured 20 AMVLs in the PLAX view and 20 AMVLs in the $\mathrm{A} 3 \mathrm{C}$ view.

\section{Statistical methods}

The statistical analysis was performed using SPSS 21 (IBM, Armonk, NY). Normally distributed continuous data are expressed as mean \pm standard deviation and non-normally distributed data as median followed by interquartile range. For comparing categorical variables Pearson's Chi-square test was used. For comparing continuous variables $t$ test was used, and Mann-Whitney $\mathrm{U}$ in case of non-normally distributed data. All analyses were two-sided; $p$ values $<0.05$ were considered significant. Inter-observer and intra-observer agreement was defined as the mean of the difference between two measurements \pm standard deviation. Univariate and multivariable cox proportional hazard regression was performed to determine hazard ratios (HR) and $95 \%$ confidence intervals (CI). After screening for multicollinearity, the univariate significant variables with the highest HR were entered into the multivariable regression model. To calculate the allowed number of variables for inclusion in the multivariable analysis, the square root of the number of events was
AMVL measured $26 \mathrm{~mm}$, and in the apical three chamber view, $\mathbf{b}$ the AMVL measured $26 \mathrm{~mm}$

used. This is an alternative method to determine the number of variables allowed for inclusion in the multivariable analysis [20].

\section{Results}

\section{Clinical evaluation}

HCM gene mutation carriers represented mutations in 10 different genes. The MYBPC3 gene was most frequently affected (77\%), followed by the MYH7 gene (11\%). Other genes affected were TNNT2 (3\%), MYL2 (2\%), FHL1 (2\%), ALPK3 (2\%) MIBI (0.75\%), TNNI3 (0.75\%), TPMI (0.75\%), and MYL3 $(0.75 \%)$. Clinical and echocardiographic characteristics in mutation carriers and controls are presented in Table 1. Mutation carriers and controls had similar age, gender, and body surface area. Compared to controls, more mutation carriers had pathological Q waves (4 vs $0 \%, p=0.02$ ), and mutation carriers had a higher $\mathrm{E} / \mathrm{e}^{\prime}$ ratio $(8.2 \pm 1.9$ vs $7.7 \pm 1.9, p=0.03)$, and a higher maximal wall thickness $(8.9 \pm 1.9$ vs $8.0 \pm 1.8 \mathrm{~mm}, p=0.001)$.

\section{AMVL measurements}

Beeswarm plots of AMVL measurements in the PLAX and the $\mathrm{A} 3 \mathrm{C}$ view are presented in Fig. 2. In the PLAX view, 
Table 1 Clinical and echocardiographic characteristics of the study population
Fig. 2 Beeswarm plot of anterior mitral valve leaflet (AMVL) length measurements in hypertrophic cardiomyopathy gene mutation carriers without hypertrophic changes versus healthy controls, assessed with transthoracic echocardiography in the a parasternal long-axis view and $\mathbf{b}$ apical three chamber view

\begin{tabular}{|c|c|c|c|}
\hline Variable & $\begin{array}{l}\text { Mutation carrier } \\
(\mathrm{n}=133)\end{array}$ & Control $(n=135)$ & $p$ value \\
\hline Age (year) & $41 \pm 14$ & $44 \pm 14$ & 0.11 \\
\hline Female gender $n(\%)$ & $85(64)$ & $73(54)$ & 0.18 \\
\hline Body surface area $\left(\mathrm{m}^{2}\right)$ & $1.9 \pm 0.2$ & $1.9 \pm 0.2$ & 0.86 \\
\hline \multicolumn{4}{|l|}{ Electrocardiography } \\
\hline Romhilt-Estes $\geq 4 n(\%)$ & $10(8)$ & $4(3)$ & 0.09 \\
\hline $\mathrm{T}$ wave inversion $n(\%)$ & $1(1)$ & $0(0)$ & 0.31 \\
\hline Pathological Q wave $n(\%)$ & $5(4)$ & $0(0)$ & 0.02 \\
\hline \multicolumn{4}{|l|}{ Echocardiography } \\
\hline Maximal wall thickness (mm) & $8.9 \pm 2.0$ & $8.0 \pm 1.8$ & $<0.001$ \\
\hline Left atrial size (mm) & $34 \pm 5$ & $34 \pm 4$ & 0.24 \\
\hline LVOT gradient $\geq 30 \mathrm{mmHg}^{\mathrm{a}} n(\%)$ & $0(0)$ & $0(0)$ & 0.50 \\
\hline AMVL, PLAX (mm) & $24 \pm 4$ & $24 \pm 4$ & 0.85 \\
\hline AMVL, A3C (mm) & $29 \pm 4$ & $30 \pm 4$ & 0.02 \\
\hline AMVL, averaged (mm) & $27 \pm 3$ & $27 \pm 3$ & 0.17 \\
\hline Chordal systolic anterior motion $n(\%)$ & $5(4)$ & $1(1)$ & 0.09 \\
\hline Leaflet systolic anterior motion $n(\%)$ & $0(0)$ & $0(0)$ & 0.50 \\
\hline $\mathrm{E} / \mathrm{A}$ ratio & $1.4 \pm 0.5$ & $1.6 \pm 0.7$ & 0.03 \\
\hline $\mathrm{E} / \mathrm{e}^{\prime}$ ratio & $8.2 \pm 1.9$ & $7.7 \pm 1.9$ & 0.03 \\
\hline Septal e' $(\mathrm{cm} / \mathrm{s})$ & $9.5 \pm 2.5$ & $9.6 \pm 2.6$ & 0.61 \\
\hline \multicolumn{4}{|l|}{ Diastolic function } \\
\hline Normal $n(\%)$ & $105(83)$ & $111(85)$ & 0.66 \\
\hline Abnormal relaxation $n(\%)$ & $10(8)$ & $7(5)$ & 0.39 \\
\hline Pseudonormal filling $n(\%)$ & $11(9)$ & $13(10)$ & 0.76 \\
\hline Restrictive filling $n(\%)$ & $0(0)$ & $0(0)$ & 0.50 \\
\hline \multicolumn{4}{|l|}{ Systolic function } \\
\hline Good $n(\%)$ & $132(99)$ & $135(100)$ & 0.31 \\
\hline Mildly reduced $n(\%)$ & $1(1)$ & $0(0)$ & 0.31 \\
\hline Moderately reduced $n(\%)$ & $0(0)$ & $0(0)$ & 0.50 \\
\hline Poor $n(\%)$ & $0(0)$ & $0(0)$ & 0.50 \\
\hline
\end{tabular}

Data are expressed as mean \pm standard deviation or as absolute and (\%)

$A M V L$ anterior mitral valve leaflet, $A 3 C$ apical three chamber view, $L V O T$ left ventricular outflow tract, $P L A X$ parasternal long-axis view

${ }^{a}$ at rest
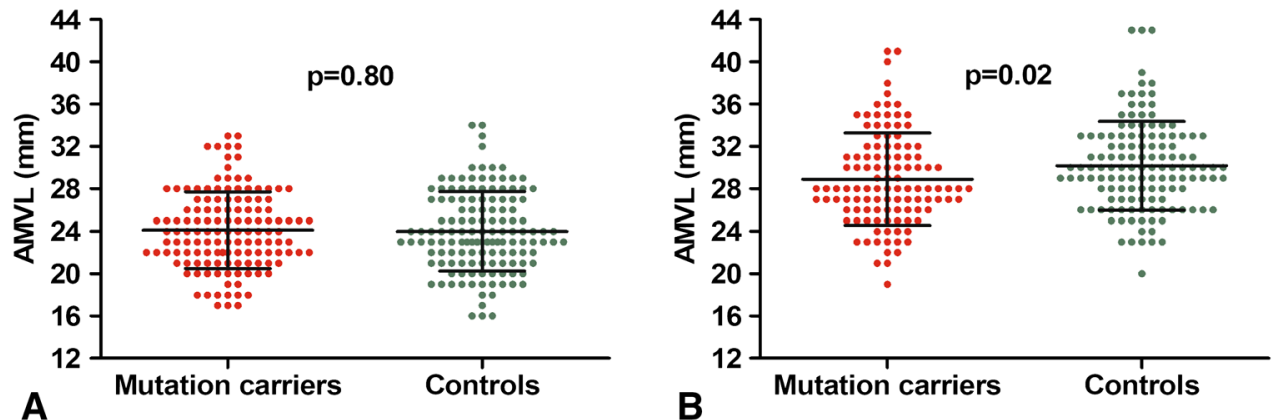

AMVL length did not differ between mutation carriers and controls ( $24 \pm 4$ vs $24 \pm 4 \mathrm{~mm}, p=0.8)$. In the A3C view, AMVL were shorter in the mutation carriers $(29 \pm 4$ vs
$30 \pm 4 \mathrm{~mm}, p=0.02)$. When averaged for both views, AMVL length was similar in mutation carriers and controls $(27 \pm 3$ vs $27 \pm 3 \mathrm{~mm}, p=0.2$ ). Overall, AMVL were significantly 
longer in the $\mathrm{A} 3 \mathrm{C}$ view than in the PLAX view $(30 \pm 4$ vs $24 \pm 4 \mathrm{~mm}, p<0.001)$.

\section{Intra-observer and inter-observer agreement}

In the PLAX view, the inter-observer agreement was $-2.7 \pm 2.6 \mathrm{~mm}$ and the intra-observer agreement was $-1.0 \pm 3.5 \mathrm{~mm}$. In the $\mathrm{A} 3 \mathrm{C}$ view, the inter-observer agreement was $2.0 \pm 2.5 \mathrm{~mm}$ and the intra-observer agreement was $0.5 \pm 2.6 \mathrm{~mm}$.

\section{Follow-up}

During $5.8 \pm 3.0$ years follow-up, $13(14 \%)$ mutation carriers developed HCM. Mean age at HCM diagnosis was $52 \pm 17$ years. In these 13 mutation carriers, maximal wall thickness increased from a median 10 (interquartile range 8, 11) $\mathrm{mm}$ to 13 (interquartile range 13,14$) \mathrm{mm}$, with a mean rate of $0.7 \pm 0.3 \mathrm{~mm} / \mathrm{year}$. Table 2 presents the baseline characteristics in those who developed HCM during follow-up and those who did not. Univariate significant predictors of the development of HCM were pathological Q wave (HR 9.74, 95\% CI 2.53-37.46, $p=0.001)$, maximal wall thickness (HR 1.64, 95\% CI 1.12-2.39, $p=0.01$ ), E/e' ratio (HR $1.63,95 \%$ CI 1.20-2.23, $p=0.002$ ), left atrial size (HR $1.16,95 \%$ CI 1.03-1.31, $p=0.01$ ), and age (HR 1.06, 95\% CI $1.02-1.11, p=0.01)$. AMVL length was not predictive

Table 2 Baseline characteristics of HCM gene mutation carriers who did and did not develop hypertrophic cardiomyopathy during followup

\begin{tabular}{lllc}
\hline Variable & \multicolumn{2}{l}{ Developed HCM } \\
\cline { 2 - 4 } & Yes $(n=13)$ & No $(n=77)$ & $p$ value \\
\hline Age (years) & $47 \pm 19$ & $39 \pm 13$ & 0.05 \\
Male gender $n(\%)$ & $8(62)$ & $25(33)$ & 0.04 \\
Romhilt-Estes $\geq 4 n(\%)$ & $1(8)$ & $5(7)$ & 0.87 \\
T wave inversion $n(\%)$ & $1(8)$ & $0(0)$ & 0.01 \\
Pathological Q $n(\%)$ & $3(23)$ & $2(3)$ & 0.003 \\
Left atrial size (mm) & $39 \pm 5$ & $33 \pm 5$ & $<0.001$ \\
Maximal wall thickness (mm) & $10 \pm 2$ & $9 \pm 2$ & 0.02 \\
AMVL, PLAX (mm) & $25 \pm 5$ & $24 \pm 3$ & 0.47 \\
AMVL, A3C (mm) & $29 \pm 5$ & $29 \pm 4$ & 0.90 \\
Chordal systolic anterior motion & $1(8)$ & $3(4)$ & 0.54 \\
$\quad n(\%)$ & & & \\
E/e' ratio & $9.3 \pm 1.8$ & $8.1 \pm 1.7$ & 0.03 \\
Septal e' (cm/s) & $8.5 \pm 2.7$ & $9.5 \pm 2.6$ & 0.20 \\
Abnormal diastolic function $n$ & $4(31)$ & $11(16)$ & 0.21 \\
$\quad$ (\%) & & & \\
\hline
\end{tabular}

Data are expressed as mean \pm standard deviation or as absolute and (\%)

$A M V L$ anterior mitral valve leaflet, $A 3 C$ apical three chamber view, $H C M$ hypertrophic cardiomyopathy, PLAX parasternal long axis view of the development of HCM in the PLAX view (HR 1.03, 95\% CI $0.87-1.22, p=0.72$ ) or in the A3C view (HR 0.99, 95\% CI 0.86-1.15, $p=0.92$ ). Multivariable cox regression analysis which included three variables demonstrates that pathological Q wave (adjusted HR 9.89, 95\% CI 2.09-46.95, $p=0.004$ ), E/e' ratio (adjusted HR 2.52, 95\% CI 1.48-4.29, $p=0.001$ ), and maximal wall thickness (adjusted HR 2.15, 95\% CI 1.36-3.42, $p=0.001$ ) all were independent predictors of HCM during follow-up.

\section{Discussion}

During HCM family screening, individuals who carry a HCM gene mutation may not fulfil the echocardiographic diagnostic criterion of HCM [5]. Because of the age-related penetrance of HCM, long-term clinical follow-up including ECG and echocardiography is recommended $[2,3]$. Currently, it is unclear which HCM mutation carriers will develop HCM $[2,11]$. We aimed to assess AMVL length in mutation carriers and controls, and determine the prognostic value of AMVL length for the development of HCM during follow-up. Our main findings are: (1) AMVL length is similar in mutation carriers and controls, (2) AMVL length is not predictive of the development of HCM, and (3) pathological $\mathrm{Q}$ wave, E/e' ratio, and maximal wall thickness are independent predictors of the development of HCM.

\section{AMVL elongation is not a primary phenotypic feature of HCM}

In patients with HCM, AMVL elongation has been demonstrated pathologically, on echocardiography, and on cardiovascular magnetic resonance imaging [10, 18, 21-23]. Among other factors, AMVL elongation contributes to systolic anterior motion of the mitral valve and LV outflow tract obstruction [23-25]. The etiology of AMVL elongation in patients with HCM is unclear. Both the pathological study of Klues et al. and the in vivo study of Kim et al. found that AMVL elongation is not secondary to LV outflow tract obstruction or systolic anterior motion of the mitral valve, since it also occurs in patients without LV outflow tract obstruction or systolic anterior motion [19, 21, 22]. Therefore, it was suggested that AMVL elongation is a primary phenotypic expression of HCM. Several studies have indeed reported AMVL elongation in mutation carriers as measured by magnetic resonance imaging $[6,7,10]$, and echocardiography [9]. The current study contradicts these findings. In line with our findings, a recent magnetic resonance imaging study similarly reported no difference in AMVL length between mutation carriers and controls [8]. The discrepancy between the studies may be related to the small number of participants, different imaging modalities 
used, different distribution of genetic mutations, or different methodologies used for AMVL measurements.

For several reasons, we believe it is unlikely that HCM gene mutations cause AMVL elongation. First, there are no sarcomeric proteins in the mitral valve leaflet [25]. Second, a HCM animal model including heterozygous cardiac myosin-binding protein $\mathrm{C}$ targeted knock-out mice embryos did not show mitral leaflet elongation [26]. Third, Captur et al. observed AMVL elongation in genotype-negative patients with HCM [10]. And finally, most morphological studies demonstrate that mitral leaflets are intrinsically normal [21, 27]. Other potential etiologies of AMVL elongation are being investigated, such as the paracrine effects from the abnormal LV wall which influences valvulogenesis, or the abnormal differentiation of pluripotent epicardial-derived cells into fibroblast-cells with increased synthesis of periostin which might drive leaflet elongation [25].

\section{Predicting the development of HCM}

The current study demonstrates that AMVL length had no predictive value for the development of HCM. Hence, AMVL length cannot be used as a preclinical marker of the development of HCM. Similar observations were made in a prior smaller study by Ho et al. [28]. Pathological Q wave had a high predictive value for the development of HCM. Indeed, prior investigation of ECGs in genotyped HCM populations demonstrated that $\mathrm{Q}$ waves and repolarization abnormalities are the most distinguishing ECG manifestations of sarcomere mutations [29]. However, the clinical utility of $\mathrm{Q}$ waves is probably limited because of the low negative predictive value; 10 out of 13 mutations that developed HCM did not have pathological Q waves at baseline. Our study did not demonstrate a prognostic value of septal e', in contrast to Ho et al. [28]. The age difference between the studies (16 vs 41 years) and differences in genetic mutations might explain this discrepancy. However, we did observe a predictive value of $\mathrm{E} / \mathrm{e}^{\prime}$ ratio, which supports the suggestion that diastolic dysfunction is a primary phenotypic feature of $\operatorname{HCM}[28,30]$.

\section{Technical challenges associated with AMVL measurement by echocardiography}

Previous studies most commonly used magnetic resonance imaging to measure AMVL length $[6-8,10]$. Since transthoracic echocardiography is the advised imaging modality in HCM clinical screening strategies and has a higher spatial and temporal resolution than cardiac magnetic resonance imaging [31, 32], we used echocardiography to determine AMVL length. Overall, inter-observer variability in both views was $2-3 \mathrm{~mm}$, similar to previous studies $[6,8,18]$. The difference between observers may be explained by the technical difficulty of distinguishing the mitral leaflet from the chordae tendineae, and by the frame-to-frame variability in AMVL length caused by AMVL movement during diastole and respiration. Intra-observer agreement was best for the $\mathrm{A} 3 \mathrm{C}$ view, which was unexpected because in the PLAX view the distance to the transducer is shorter. It may be explained by the landmarks that were used; in the A3C view the insertion of the noncoronary aortic leaflet is more easily identifiable in comparison to the hinge point in the PLAX view. Finally, AMVL were significantly longer in the $\mathrm{A} 3 \mathrm{C}$ view than in the PLAX view; the measurement in the $\mathrm{A} 3 \mathrm{C}$ view included the intervalvular fibrosa.

\section{Limitations}

This study has several limitations. First, although the study population is large compared to previous studies, a higher sample size would reduce the risk of sampling error. Second, the proportion of HCM gene mutation carriers that developed HCM during follow-up was limited.

\section{Conclusions}

AMVL length is similar in HCM mutation carriers and healthy controls. AMVL length is not a predictor of the development of HCM during follow-up, in contrast to pathological Q wave, E/e' ratio, and maximal wall thickness.

\section{Compliance with ethical standards}

Conflict of interest The authors declare that they have no conflict of interest.

Ethical approval All procedures performed in studies involving human participants were in accordance with the ethical standards of the institutional and/or national research committee and with the 1964 Helsinki declaration and its later amendments or comparable ethical standards.

Informed consent Informed consent was obtained from all individual participants included in the study.

Open Access This article is distributed under the terms of the Creative Commons Attribution 4.0 International License (http://creativeco mmons.org/licenses/by/4.0/), which permits unrestricted use, distribution, and reproduction in any medium, provided you give appropriate credit to the original author(s) and the source, provide a link to the Creative Commons license, and indicate if changes were made.

\section{References}

1. Semsarian C, Ingles J, Maron MS, Maron BJ (2015) New perspectives on the prevalence of hypertrophic cardiomyopathy. J Am Coll Cardiol 65(12):1249-1254 
2. Elliott PM, Anastasakis A, Borger MA, Borggrefe M, Cecchi F, Charron P, Hagege AA, Lafont A, Limongelli G, Mahrholdt H, McKenna WJ, Mogensen J, Nihoyannopoulos P, Nistri S, Pieper PG, Pieske B, Rapezzi C, Rutten FH, Tillmanns C, Watkins H (2014) ESC Guidelines on diagnosis and management of hypertrophic cardiomyopathy: the Task Force for the Diagnosis and Management of Hypertrophic Cardiomyopathy of the European Society of Cardiology (ESC). Eur Heart J 35(39):2733-2779

3. Gersh BJ, Maron BJ, Bonow RO, Dearani JA, Fifer MA, Link MS, Naidu SS, Nishimura RA, Ommen SR, Rakowski H, Seidman CE, Towbin JA, Udelson JE, Yancy CW (2011) 2011 ACCF/ AHA guideline for the diagnosis and treatment of hypertrophic cardiomyopathy: a report of the American College of Cardiology Foundation/American Heart Association Task Force on Practice Guidelines. J Thorac Cardiovasc Surg 142(6):e153-e203

4. Ho CY, Charron P, Richard P, Girolami F, Van SpaendonckZwarts KY, Pinto Y (2015) Genetic advances in sarcomeric cardiomyopathies: state of the art. Cardiovasc Res 105(4):397-408

5. Olivotto I, Cecchi F, Poggesi C, Yacoub MH (2012) Patterns of disease progression in hypertrophic cardiomyopathy: an individualized approach to clinical staging. Circ Heart Fail 5(4):535-546

6. Maron MS, Olivotto I, Harrigan C, Appelbaum E, Gibson CM, Lesser JR, Haas TS, Udelson JE, Manning WJ, Maron BJ (2011) Mitral valve abnormalities identified by cardiovascular magnetic resonance represent a primary phenotypic expression of hypertrophic cardiomyopathy. Circulation 124(1):40-47

7. Captur G, Lopes LR, Mohun TJ, Patel V, Li C, Bassett P, Finocchiaro G, Ferreira VM, Esteban MT, Muthurangu V, Sherrid MV, Day SM, Canter CE, McKenna WJ, Seidman CE, Bluemke DA, Elliott PM, Ho CY, Moon JC (2014) Prediction of sarcomere mutations in subclinical hypertrophic cardiomyopathy. Circ Cardiovasc Imaging 7(6):863-871

8. Tarkiainen M, Sipola P, Jalanko M, Helio T, Laine M, Jarvinen V, Hayrinen K, Lauerma K, Kuusisto J (2016) Cardiovascular magnetic resonance of mitral valve length in hypertrophic cardiomyopathy. J Cardiovasc Magn Reson 18(1):33

9. Peyrou J, Reant P, Reynaud A, Cornolle C, Dijos M, RooryckThambo C, Landelle M, Montaudon M, Laurent F, Roudaut R, Lafitte $S$ (2016) Morphological and functional abnormalities pattern in hypertrophy-free HCM mutation carriers detected with echocardiography. Int J Cardiovasc Imaging 32(9):1379-1389

10. Captur G, Lopes LR, Patel V, Li C, Bassett P, Syrris P, Sado DM, Maestrini V, Mohun TJ, McKenna WJ, Muthurangu V, Elliott PM, Moon JC (2014) Abnormal cardiac formation in hypertrophic cardiomyopathy: fractal analysis of trabeculae and preclinical gene expression. Circ Cardiovasc Genet 7(3):241-248

11. Cardim N (2017) Clinical detection of mutation carriers of hypertrophic cardiomyopathy in perspective: is cardiac imaging the crystal ball of the cardiologist? Eur Heart J Cardiovasc Imaging 18(4):390-391

12. van Velzen HG, Vriesendorp PA, Oldenburg RA, van Slegtenhorst MA, van der Velden J, Schinkel AF, Michels M (2016) Value of genetic testing for the prediction of long-term outcome in patients with hypertrophic cardiomyopathy. Am J Cardiol 118(6):881-887

13. Michels M, Hoedemaekers YM, Kofflard MJ, Frohn-Mulder I, Dooijes D, Majoor-Krakauer D, Ten Cate FJ (2007) Familial screening and genetic counselling in hypertrophic cardiomyopathy: the Rotterdam experience. Neth Heart J 15(5):184-190

14. Menting ME, McGhie JS, Koopman LP, Vletter WB, Helbing WA, van den Bosch AE, Roos-Hesselink JW (2016) Normal myocardial strain values using $2 \mathrm{D}$ speckle tracking echocardiography in healthy adults aged 20-72 years. Echocardiography 33(11):1665-1675

15. Nagueh SF, Bierig SM, Budoff MJ, Desai M, Dilsizian V, Eidem B, Goldstein SA, Hung J, Maron MS, Ommen SR, Woo A (2011) American society of echocardiography clinical recommendations for multimodality cardiovascular imaging of patients with hypertrophic cardiomyopathy: endorsed by the American society of nuclear cardiology, society for cardiovascular magnetic resonance, and society of cardiovascular computed tomography. J Am Soc Echocardiogr 24(5):473-498

16. Lang RM, Badano LP, Mor-Avi V, Afilalo J, Armstrong A, Ernande L, Flachskampf FA, Foster E, Goldstein SA, Kuznetsova T, Lancellotti P, Muraru D, Picard MH, Rietzschel ER, Rudski L, Spencer KT, Tsang W, Voigt JU (2015) Recommendations for cardiac chamber quantification by echocardiography in adults: an update from the American society of echocardiography and the European association of cardiovascular imaging. Eur Heart J Cardiovasc Imaging 16(3):233-270

17. Nagueh SF, Appleton CP, Gillebert TC, Marino PN, Oh JK, Smiseth OA, Waggoner AD, Flachskampf FA, Pellikka PA, Evangelisa A (2009) Recommendations for the evaluation of left ventricular diastolic function by echocardiography. Eur J Echocardiogr 10(2):165-193

18. Klues HG, Proschan MA, Dollar AL, Spirito P, Roberts WC, Maron BJ (1993) Echocardiographic assessment of mitral valve size in obstructive hypertrophic cardiomyopathy. Anatomic validation from mitral valve specimen. Circulation 88(2):548-555

19. Alhaj EK, Kim B, Cantales D, Uretsky S, Chaudhry FA, Sherrid MV (2013) Symptomatic exercise-induced left ventricular outflow tract obstruction without left ventricular hypertrophy. J Am Soc Echocardiogr 26(5):556-565

20. Altman DG (1990) Practical Statistics for Medical Research. Taylor \& Francis Ltd, Milton Park

21. Klues HG, Maron BJ, Dollar AL, Roberts WC (1992) Diversity of structural mitral valve alterations in hypertrophic cardiomyopathy. Circulation 85(5):1651-1660

22. Kim DH, Handschumacher MD, Levine RA, Choi YS, Kim YJ, Yun SC, Song JM, Kang DH, Song JK (2010) In vivo measurement of mitral leaflet surface area and subvalvular geometry in patients with asymmetrical septal hypertrophy: insights into the mechanism of outflow tract obstruction. Circulation 122(13):1298-1307

23. Teo EP, Teoh JG, Hung J (2015) Mitral valve and papillary muscle abnormalities in hypertrophic obstructive cardiomyopathy. Curr Opin Cardiol 30(5):475-482

24. Sherrid MV, Balaram S, Kim B, Axel L, Swistel DG (2016) The Mitral Valve in Obstructive Hypertrophic Cardiomyopathy: a Test in Context. J Am Coll Cardiol 67(15):1846-1858

25. Levine RA, Hagege AA, Judge DP, Padala M, Dal-Bianco JP, Aikawa E, Beaudoin J, Bischoff J, Bouatia-Naji N, Bruneval P, Butcher JT, Carpentier A, Chaput M, Chester AH, Clusel C, Delling FN, Dietz HC, Dina C, Durst R, Fernandez-Friera L, Handschumacher MD, Jensen MO, Jeunemaitre XP, Le Marec H, Le Tourneau T, Markwald RR, Merot J, Messas E, Milan DP, Neri T, Norris RA, Peal D, Perrocheau M, Probst V, Puceat M, Rosenthal N, Solis J, Schott JJ, Schwammenthal E, Slaugenhaupt SA, Song JK, Yacoub MH, Leducq N (2015) Mitral transatlantic, mitral valve disease-morphology and mechanisms. Nat Rev Cardiol 12(12):689-710

26. Captur G, Ho CY, Schlossarek S, Kerwin J, Mirabel M, Wilson R, Rosmini S, Obianyo C, Reant P, Bassett P, Cook AC, Lindsay S, McKenna WJ, Mills K, Elliott PM, Mohun TJ, Carrier L, Moon JC (2016) The embryological basis of subclinical hypertrophic cardiomyopathy. Sci Rep 6:27714

27. Teare D (1958) Asymmetrical hypertrophy of the heart in young adults. Br Heart J 20(1):1-8

28. Ho CY, Cirino AL, Lakdawala NK, Groarke J, Valente AM, Semsarian C, Colan SD, Orav EJ (2016) Evolution of hypertrophic cardiomyopathy in sarcomere mutation carriers. Heart. https:// doi.org/10.1136/heartjnl-2016-310015 
29. Lakdawala NK, Thune JJ, Maron BJ, Cirino AL, Havndrup O, Bundgaard H, Christiansen M, Carlsen CM, Dorval JF, Kwong RY, Colan SD, Kober LV, Ho CY (2011) Electrocardiographic features of sarcomere mutation carriers with and without clinically overt hypertrophic cardiomyopathy. Am J Cardiol 108(11):1606-1613

30. Kauer F, van Dalen BM, Michels M, Soliman OI, Vletter WB, van Slegtenhorst M, ten Cate FJ, Geleijnse ML (2013) Diastolic abnormalities in normal phenotype hypertrophic cardiomyopathy gene carriers: a study using speckle tracking echocardiography. Echocardiography 30(5):558-563

31. Lin E, Alessio A (2009) What are the basic concepts of temporal, contrast, and spatial resolution in cardiac CT? J Cardiovasc Comput Tomogr 3(6):403-408

32. To AC, Flamm SD, Marwick TH, Klein AL (2011) Clinical utility of multimodality LA imaging: assessment of size, function, and structure. JACC Cardiovasc Imaging 4(7):788-798

\section{Affiliations}

\section{Hannah G. van Velzen ${ }^{1}\left(\mathbb{D}\right.$. Arend F. L. Schinkel ${ }^{1} \cdot$ Myrthe E. Menting $^{1} \cdot$ Annemien E. van den Bosch $^{1}$. Michelle Michels ${ }^{1}$}

Hannah G. van Velzen

h.g.vanvelzen@erasmusmc.nl
1 Department of Cardiology, Thorax-center, Erasmus Medical Center, 's-Gravendijkwal 230, 3015 CE Rotterdam, The Netherlands 